\title{
Speaking Activities to Foster Students' Oral Performance at a Public School
}

\author{
Bocanegra Bonilla Carolina $^{1} \&$ Ramirez Valencia Astrid ${ }^{1}$ \\ ${ }^{1}$ Universidad Distrital Francisco José de Caldas, Faculty of Science and Education, Bogotá, Colombia \\ Correspondence: Bocanegra Bonilla Carolina, Faculty of Science and Education, Universidad Distrital Francisco \\ José de Caldas, Bogotá, Colombia. E-mail: miss.carolina@aol.com
}

Received: June 9, 2018 Accepted: July 11, 2018 Online Published: July 13, 2018

doi: 10.5539/elt.v11n8p65 URL: http://doi.org/10.5539/elt.v11n8p65

\begin{abstract}
By employing an action research framework, this study was designed to explore the effectiveness of a set of speaking activities centered on a children's cartoon to improve oral performance in the EFL classroom. The participants were fourth graders of a public school in Colombia, who had low oral performance in spoken English language. The findings suggest that the proposed speaking activities were comprehensible for the students, and appropriate to the students' proficiency level. Although to maximize learners' opportunities to speak in the classroom, teachers should design activities that provide chances to talk in English. Thus students will be engaged to participate in the classroom. Also, most of the students were comfortable speaking during the activities since they were familiar with watching cartoons, thus being at ease with certain topics can help students exchange ideas in class. The most important recommendation is to avoid translating instruction into students' mother tongue for the purpose to familiarize students with the target language.
\end{abstract}

Keywords: cartoons, teaching strategies, oral production, EFL, speaking activities

\section{Introduction}

Based on our teaching experience as an English teacher at the school level, we have noticed some repetitive behavior inside the English as a foreign language (EFL) classroom. First of all, students tend to have low participation in the classes and also oral practice has been a daunting challenge for language teachers. In Colombia, which is the location for this study, English is taught in elementary and secondary education. Even though English is becoming an essential subject in students' education, students do not seem to use the foreign language outside of the classroom, which reflects on their low performance and lack of motivation to participate in English classroom activities.

Findings from a previous case study at an American university involving three students of advance Italian demonstrates how using video cartoons are a valuable tool that creates a constructive environment to acquire English as a second language. These students conveyed strong motivation due to the low affective filter environment when learning English while watching cartoons (Rule \& Argue, 2015), as well as increased their participation, and their vocabulary range expanded. Using video materials into the curriculum has often been suggested for its value in teaching English as a foreign language. However, not many studies have investigated the use of cartoons to foster oral performance in the Colombian context, possibly due to the difficulty in designing a video-based curriculum or the lack of resources present in some schools. With the aim of addressing the low-performance issue, we decided to implement a pedagogical experience by using a set of speaking activities based on a students' favorite cartoon Adventure Time. Thus, this paper examines how using audiovisual aids in the teaching of English are an effective source to get students' attention and to stimulate significant learning.

\section{Theoretical Framework}

\subsection{Children's Television}

Television has played a significant role in children's lives due to its increased availability and cultural significance. Traditionally television has been considered as an anti-educational tool as children who watch many TV programs tend to spend less time reading, doing homework or interacting with others. However, as educators, we can strongly benefit from using television in the classroom to provide English as foreign language 
(EFL) learners with new experiences and enhance their listening and speaking skills.

According to Fisch (2004), "educational television refers to television programs that are intended to educate or benefit children" (p. 7). Two examples of famous educational programs widely watched around the world are Sesame Street and Dora the Explorer. Sesame Street is targeted at children from three to five years old and uses puppets, animation, and stories. To convey its message, focusing on recognizing the alphabet, numbers, body parts, shapes, sorting and classification skills. Various studies have demonstrated that Sesame Street is an educational program that provides long-term educational benefits for children (Baydar et al., 2009). Whilst, Dora the Explorer aims at children from preschool to seven years old is designed to improve children's problem-solving skills, and also teaches essential Spanish words and phrases. Thus, when Dora and some other characters are speaking directly to the children, they invite kids to participate actively and provide opportunities for them to answer. (Linebarger \& Walker, 2005)

Additionally, Anderson et al. (2000) reported that there had been positive effects on using educational television on children's development. First of all, some educational benefits are letter-word knowledge, math skills, vocabulary range, and school readiness. Likewise, changes in children's social behavior such as a better attitude towards school and non-aggressive relationship with peers.

Besides using educational programs, teachers have used videos as part of their teaching strategies. CanningWilson (2000) claims that the use of video as an educational medium of instruction stimulates and motivates students' interest since it offers foreign and second language learners opportunities to understand comprehensible input (authentic language). She conducted a large-scale survey in 2000 on using videos in the foreign language classroom, and one of her findings was that students prefer action and entertainment films than language movies or documentaries.

For example, a Youtube learning study by Mayoral, Tello and Gonzalez (2010) suggests that using technology in the classroom helps learners to build active learning, increases students' level of attention, and promotes significant learning (real-life experiences). YouTube.com is an example of a website where teachers can present a variety of videos as teaching aids in their classrooms. However, said videos have to be chosen based on students' current academic levels. In the case of preschoolers and kindergarten videos of nursery rhymes, stories, and songs used as an early stimulation resource. Elementary school students tend to prefer videos of science projects, songs, and cartoons whilst teenagers enjoy watching music videos, video documentaries about singers, artists and movie trailers.

Another example of using videos as a teaching method was a study educating students through movies. (P. Blasco, Moreto, M. Blasco, Levites, \& Janaudis, 2015) describe teaching with movies as an innovative method since it engages students to deal and reflect on own attitudes based on the movie characters. Some teaching strategies used when teaching with movies included encouraging students to engage in small group discussions then subsequently setting specific goals or activities.

In order to achieve this, it is crucial to understand and learn about some of the favorite shows students are watching at home. Usually, these TV shows have some learning. Teachers can make connections between the shows and what students are studying in class. In fact, including popular shows as part of the lesson, students are more likely to pay attention and stay focused as well as they are exposed to authentic examples of every day English used.

According to Brackman (1956), cartoons can be used for different purposes. He categorizes them into five general areas of use:

A. Cartoons as a means to improve the teacher-student relationship.

B. Cartoons as a useful class tool to stimulate and maintain student interest.

C. Cartoons as reinforcement of concepts studied in class.

D. Cartoons can develop significant attitudes in students' learning process.

E. Cartoons as a way to reduce classroom tension.

Additionally, Brackman points out that to know if a cartoon is useful in the classroom, it should satisfy four criteria (1956, p. 270):

I. Is the cartoon constructive?

II. Will the cartoon capture students' interest?

III. Is the cartoon directly related to the subject being studied? 
IV. Does the cartoon focus on the importance of English skills in everyday living?

Taking into account Brackman's cartoons areas of use, one of the most popular cartoons out there was chosen for this pedagogical intervention- Adventure time- The main characters are Finn who is a 12-year-old human and Jake a talking shape-shifting dog. They inhabit the world of Ooo, a wonderland of cupcakes, trains, an evil king, and princesses. On each episode Jake the dog and Finn the human go on an adventure. The episodes last 12 minutes long and they foster honesty, friendship and showing kindness to everyone whether viewer agrees with them or not. In this case, Adventure Time was used during the classes to stimulate and maintain students' interest and engage them in participating in class discussions and speaking activities related to the episode they watched. Most importantly, this cartoon attracts students' attention, and it contains simple stories with brief and clear conversations among the characters, subconsciously reinforcing the target language learned in class by students.

\subsection{Oral Performance}

Oral language is the ability to listen and speak. These essential everyday skills can improve with age-appropriate instruction and practice. However, English teachers face low oral performance in their classes due to different reasons. For example, syllabus focused on vocabulary memorization, non-communicative activities, contextual constraints of space, time and resources (Urquijo, 2012). As a consequence, students have poor participation and interaction during English classes.

Although oral language is used in most classrooms, students often become passive speakers since the teacher and not the students do almost all the talking. As Palmer (2014) indicates teachers who include oral activities into their classroom instruction will not automatically make learners good speakers. As revealed by Troute (2016) when teaching second language learners, it is pertinent to encourage students to express their ideas and not to focus on language and correct grammar as well to allow students with enough time to practice.

Considering that the majority of our communication is oral and our students are exposed continuously to face to face interactions with classmates and peers, we must consider that is necessary to plan lessons that enhance students' oral production. Based on Goh and Burns (2012) to foster oral performance in the foreign language, we need to take into account three key factors: teachers, materials, and learners.

I. Teachers: should help learners to acquire language and skills that they will not be able to achieve on their own.

II. Materials: they should facilitate second language speaking development. Materials should fall into three categories:

a. Those that provide speaking practice.

b. Those that promote language and skill learning.

c. Those that facilitate meta-cognitive development.

III. Learners: should be encouraged to take responsibility for managing their learning and improving their speaking.

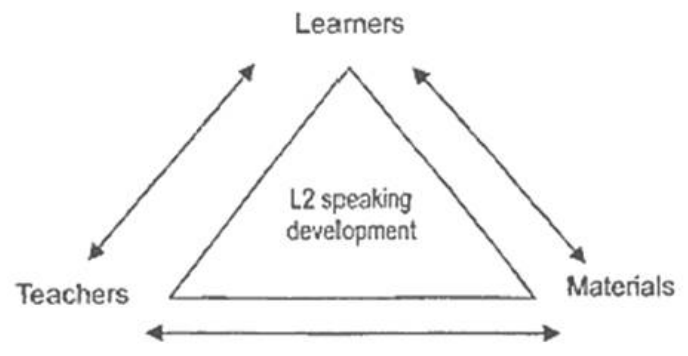

Figure 1. Three critical success factors in the second language speaking development

For this reason, during this intervention, we decided to include class discussions in class after watching the chosen Adventure Time episode since discussions promote understanding. As stated Hammond and Nessel (2011) when students participate in class discussions, they are more likely to retain information. In the same way, we need to recognize that communication methods have evolved; the use of videos in our classroom is in demand. Therefore, it is noteworthy to incorporate multimedia to make our instruction more powerful and promote students' understanding. By doing so, we are creating opportunities in the classroom for students to 
express their thoughts and opinions as well as to make sense of new information. We will include talking activities during the intervention such as: teacher directed/discussion whole-class teaching, talk partners, brainstorming, circle time, etc., as teaching strategies to stimulate children oral production in the classrooms. (Grugeon, Dawes, Smith, \& Hubbard, 2005).

\section{Method}

\subsection{Setting and Participants}

This pedagogical intervention was carried out in a public school located in Bogotá, Colombia. The school consisted of two different sections, Section A offering Elementary Education (kindergarten through fifth grade) and Section B offering secondary education (sixth to eleventh grade). Our intervention will take place in the Section A. The entire school's curriculum places emphasis on the development of communicative skills in the first language as well as English as a foreign language.

The target population selected for this intervention study was a group of fourth graders between 9 and 12 years old. All participants were volunteers, and parental permission was required before starting the pedagogical intervention.

During the observed lessons, children generally seemed interested in learning English, followed their teacher's instructions and actively participated in the class. Most students had been learning English in the school beforehand. Taking English classes four hours a week since they were enrolled in this school with classes take place predominantly on Wednesdays and Thursdays.

\subsection{Action Research}

Even though this article presents a pedagogical intervention, we also chose to follow the principles of action research because it is a valuable way to enhance teaching practices, increase our understanding as teachers, and of our students. In Burns' view (2010), Action research (AR) is an approach where teachers look closely at classroom issues. It aims to improve teaching practices through improving students' learning processes. In our case, we realized that students had a low level of oral production during the English class. Therefore, we decided to use a set of speaking activities based on students' favorite TV shows. The activities were designed as a means to increase students' speaking sill in the English classes.

According to Kemmis and McTaggart (1988) add that AR involves four phases (see Figure 2):

1. Planning

2. Action

3. Observation

4. Reflection

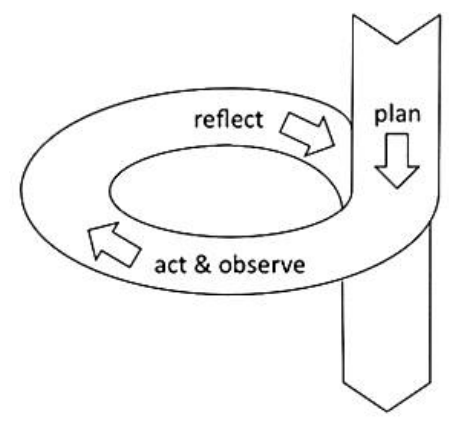

Figure 2. Action Model phases based on Kemmis and McTaggart (1988)

When following the action research method, teachers begin the process by identifying a problem or matter in the classroom and develop an action plan that will improve their teaching practice. Then, intervention takes place in the classroom; simultaneously educators observe effects of the intervention and start collecting data based on their classroom observations. As a result of the intervention, teachers finally reflect on, evaluate and describe effects of the intervention.

Throughout our study, we carefully followed the four phase of Action research. Firstly, we identified as the primary matter in our classroom that students had low participation. Then, we chose one of the students' favorite 
cartoons - Adventure Time- and planed speaking activities based on the cartoon to improve students' oral production. Next, we carried out three sessions where students participated in the speaking activities after watching the selected Adventure Time episode. These sessions allowed us to closely observe the effects of using cartoons as a learning tool to improve learners' oral performance while collecting data using teacher journals, classroom observation, and semi-structured interviews. Finally, we reflected upon the pedagogical experience and described what happened in the classes and how students reacted to the use of these speaking activities.

\subsection{Instruments}

To collect data during this pedagogical intervention, we selected three different instruments: peer observation, reflective journal, and semi-structured interviews. Burns (2010) declares how observing and describing play an essential role in action research because they allow teachers to notice classroom issues and become aware of them. Thus, peer observation was one of the instruments used during the pedagogical experience bearing in mind that another teacher observed the class and wrote what happened during the class. Additionally, the observing teachers provided suggestions and essential notes to be taken into consideration in the oncoming lessons.

Subsequently, we compiled a reflective teacher journal after the lesson as a method of capturing what occurred in the class to assist us in gathering insights and feelings towards the use of speaking activities with fourth graders. As Mills (2007) remarks, a journal is a classic tool to keep a narrative account not only of class observations but also feelings related to the research process. It provides an ongoing means to capture relevant reflections and events associated with the pedagogical intervention.

Furthermore, we created a semi-structured interview for students. The interview provided more details on how students were feeling after the lesson. For instance, we developed a set of two questions on using speaking activities to enhance students' verbal skill. One of the questions was a closed-ended question whilst the other was an open-ended question. The interview was administered as a classroom task at the end of the class. Students interviewed each other instead of the teacher asking them the questions. By doing this, it felt that students would provide an honest answer. Burns (2010) suggests that these types of interviews are structured and organized but at the same time open, aiming to enable the interviewers to make comparisons across participants' responses.

The data collected emerged from three different instruments: peer observation, reflective journal and semi-structured interviews that allowed us to contrast the information and follow the triangulation principle, considering that methodological triangulation means to collect data in different ways and not only relying on one instrument (Mills, 2007, p. 56). Thus, the use of these three instruments was crucial to map out and explain the benefits of using speaking activities to promote oral participation by studying it from more than one standpoint.

\subsection{Description of the Activities}

During this intervention, we designed three activities linked to three Adventure Time episodes (Table 1); each activity aimed at enhancing students' speaking skill.

Table 1. Activities and episodes' summaries

\begin{tabular}{|c|c|c|}
\hline Activity & Episode & Episode Summary \\
\hline What happens next? & $\begin{array}{l}\text { "Earth and Water" } \\
\text { Season 5. Episode } 31\end{array}$ & $\begin{array}{l}\text { Flame princess is upset because she argued with } \\
\text { Finn. Meanwhile Princess Bubblegum tried to } \\
\text { help her. Finally, Finn apologized for his wrong } \\
\text { actions, and Flame Princess forgave him. They } \\
\text { kept being friends as long as they are honest with } \\
\text { each other. }\end{array}$ \\
\hline What are they like? & $\begin{array}{l}\text { "Play date" } \\
\text { Season 5. Episode } 38\end{array}$ & $\begin{array}{l}\text { Finn and Jake called Abracadaniel to befriend Ice } \\
\text { King. Ice King and Abracadaniel became quick } \\
\text { friends, and they ended up their play date with a } \\
\text { dance show. }\end{array}$ \\
\hline What are they talking about? & $\begin{array}{l}\text { "Princess Potluck" } \\
\text { Season 6. Episode } 17\end{array}$ & $\begin{array}{l}\text { Princess Bubblegum organized a potluck inviting } \\
\text { her friends. Ice king wanted to ruin the potluck } \\
\text { because he was not invited and when he asked } \\
\text { the Princess Bubblegum, he found out that the } \\
\text { invitation was in the mail, but he never opened it. } \\
\text { He apologized and joined the potluck. }\end{array}$ \\
\hline
\end{tabular}




\subsubsection{Activity 1: What Happens Next?}

Students sat in a semi-circle, we played the episode "Earth and Water" with the sound muted; silence provided the same lack of vocal expression for everyone. We then discussed what might be happening and wrote students' ideas on the board. Attempting to stimulate conversation in a controlled manner. Afterward, we played the episode with sound and stopped it at regular intervals, asking students: What is happening? What do you think might happen next? Responses from students were elicited and recorded on the board. Lastly, the remainder of the video was played to see if students' predictions were right. The purpose of this activity was to practice story events predictions as well as to initiate an authentic discussion based on a cartoon topic.

\subsubsection{Activity 2: What Are They Like?}

Before starting the activity, we familiarized students with characters from today's episode. We introduced vocabulary related to personality traits such as nice, mean, angry, friendly, etc. Then, we played the entire episode "Play date" and students responded questions related to the characters like age, personality, and hobbies. We also posed questions such as how are the characters feeling? Why is he/she feeling that way? We organized students in pairs, students chose one of the characters from the episode, and they described it to their classmates. Finally, we wrote a characters' profile using all students' ideas. The primary purpose of this activity was to practice how to describe people and to foster pair work as a way to promote collaborative learning while creating opportunities for students to communicate with their classmates.

\subsubsection{Activity 3: What Are They talking About?}

Students sat in a semi-circle again, we played the episode "Princess Potluck" without Spanish captions and in pairs students speculated on characters' moods, and what was happening between them, the teacher wrote students' ideas on the board. Then, we played the episode again using Spanish subtitles and checked ideas written on board with students' help. We asked comprehension questions: Who was in the party? How was the Ice King feeling for not being at the party? Who won the raffle? We set up groups of three students, and they had to create a birthday party poster, they included food, activities to do during the party and place. Groups described birthday party posters to the class, and we picked the best birthday party idea. This activity was designed to practice giving opinions about a story, and the group activity focused on students' creativity in thinking up own ideas to create birthday party posters and explaining them to their peers.

\section{Results and Analysis}

The findings of this pedagogical intervention demonstrate that using speaking activities based on children's cartoons can help to foster the oral production of students for two main reasons. Firstly, the use of these cartoons as a learning tool engaged students and consequently positively impacting their attitudes towards learning English. Secondly, the speaking activities also served as a catalyst to increase students' participation by creating a collaborative learning experience.

\subsection{Motivation}

We observed during the pedagogical intervention that using an animated TV show as part of the English class was an effective way to obtain the attention of students. As the majority of students displayed an active level of engagement whilst watching the Adventure Time episodes, as well as the subsequent classroom activities related to the show. Since students were not aware that they were watching videos as a pedagogical tool to improve students' oral production in English, their motivation increased due to the exposure to new vocabulary and expressions through one of their favorite TV Shows. As Winke (2005) states, motivation is the component of learning which has more influence than others in a foreign language classroom due to the positive contributions it can have on learners' attitudes towards learning a new language. This is exemplified by reviewing students' interview answers as it is quite clear that they found it interesting to have an English class where they could watch a cartoon and learn at the same time. The following are comments from students about what they liked from the different speaking activities:

I enjoyed speaking in English during the class (S1)

Today was a different class because in the previous English classes we had to write and answer questions, but today we watched Adventure Time and went to another classroom, then we talked about the episode, and we liked it. (S2)

We like today's English class because we watch Finn and Jake (Adventure Time main characters), we learned our classmates'names and Adventure Time characters names in English too. (S3)

Today's class was fun because we watched TV and did an activity with our classmates about it. We had a good 
time. (S4)

\subsection{Students' Participation}

Different student behaviors showed upon reviewing the teachers' reflective journals and the classroom observations. For instance, in the first lesson when we watched an episode on the importance of being honest with friends; we realized that this activity enhanced students' creativity because students had to predict events that could happen in the chosen episode. Additionally, we noticed that some students initially lacked the confidence to predict what was going to happen, however, when other classmates began to participate, the more reserved students also decided to share their predictions with the class too. During the first lesson, regardless pupils' lack of vocabulary, we encouraged students to share their ideas, so in this sense, while learning a language, it is important to lower students' affective filter by identifying mistakes as normal (Dulay \& Burt, 1977).

This helped to aid further participation in interactive classroom activities such as creating characters' profile based on his/her behavior on the lesson episode and designing a birthday party poster. Providing our students with opportunities to practice and exchange ideas with their peers through pair and group work. Whilst also allowed a constructive dialogue among students and teachers. Likewise, students participated actively while practicing new vocabulary. Besides, we found out that students took part enthusiastically when doing these pair and group work activities, because they had a chance to work with their friends and teacher was guiding them throughout the process. As Dewey (1997) argues participation in the classroom is an essential part of foreign/second language learning process. Therefore, students should engage in their classroom activities.

Some of the students' interview responses answers relating the use of speaking activities during their English class were:

I liked that we watched a cartoon and also that the teacher paused it and asked questions about it, so we can say what we think of the episode. (S5)

I had fun talking about how the characters were feeling during the episode, and we laughed a lot when the Ice King was with the rabbits. (S6)

I enjoyed the class because the teacher let us do the activity with my friends. (S7)

I liked that the teacher asked questions and explain the words when we didn't understand. (S8)

\section{Conclusions}

In conclusion, this study's results show that using cartoons as an innovative teaching strategy improved students' oral performance in children. This use of cartoons in the classroom and including speaking activities not only promoted oral participation but also interaction between students. Furthermore, this pedagogical intervention revealed that students enjoyed their English lessons and got more interested in learning and participating in the classes because the classroom materials were entertaining and appealing to the kids. As a result, we recommend that English teachers include the use of cartoons as a teaching aid, as they are not only engaging but also motivate students to talk in English.

Additionally, we can conclude that English teachers can enrich students learning experiences by displaying videos and different media sources found on the Internet, hence exposing students to the target language in different contexts.

Finally, students will further benefit if teachers do not translate all classroom instructions into Spanish, as students become acclimatized, ensuring that whenever their teachers do not translate every instruction, students will not complete successfully class activities.

\section{References}

Avila, H. A. (2015). Creativity in the English class: Activities to promote EFL learning. HOW, 22(2), 91-103. https://doi.org/10.19183/how.22.2.141

Blasco, P. G., Moreto, G., Blasco, M. G., Levites, M. R., \& Janaudis, M. (2015). Education through Movies: Improving teaching skills and fostering reflection among students and teachers. Journal for Learning through the Arts, 11(1).

Brackman, W. (1956). Cartoons in the English Class. The Clearing House, 30(5), 268-270. https://doi.org/10.1080/00098655.1956.11476414

Burns, A. (2010). Doing action research in English language teaching: A guide for practitioners. New York, NY: Routledge. 
Canning-Wilson, C. (2000). Role of Video in the F/SL Classroom (pp. 69-76). In S. Riley, S Troudi, \& C. Coombe. (Ed.) Teaching, Learning and Technology, TESOL Arabia 1999 Conference Proceedings, TESOL Arabia 1999 Conference March 8-10, 1999.

Curtis, A. (2015). Learning English through the language of Pokémon. In D. Nunan, \& J. Richards (Eds.), Language learning beyond the classroom (pp. 129-137). New York, NY: Routledge.

Fionatankard. (2014). 7 ESL Video Activities That Your Students Will Love. In FluentU English educator blog. Retrieved from https://www.fluentu.com/blog/educator-english/esl-video-activities-lessons-clips/

Fisch, S. (2004). Children's learning from educational television: Sesame Street and beyond. Mahwah, NJ: Lawrence Erlbaum Associates, Publishers.

Fisch, S. (2005). Children's learning from television. Televizion, 18, 10-14. Retrieved from http://www.br-online.de/jugend/izi/english/publication/televizion/18_2005_E/fisch.pdf

Goh, C. C. M., \& Burns, A. (2012). Teaching speaking: a holistic approach. New York, US: Cambridge University Press.

Grugeon, E., Dawes, L., Smith, C., \& Hubbard, L. (2005). Teaching speaking \& listening in the primary school (3rd ed.). London, UK: David Fulton Publishers.

How television can actually help learning. Retrieved from http://www.teachhub.com/how-television-can-actually-help-learning

Hughes, R. (2011). Teaching and researching speaking (2nd Ed.). London, UK: Pearson.

Lin, P., \& Chanturia-Siyanova, A. (2015). Internet television for L2 vocabulary learning. In D. Nunan, \& J. Richards (Eds.), Language learning beyond the classroom (pp. 149-158). New York, NY: Routledge.

Lonsdale, M. (2010). Using television to improve learning opportunities for Indigenous Children. Australian Council for Educational Research.

Maranzana, E. (2014). Using YouTube to enhance L2 listening skills: animated cartoons in the Italian classroom. Retrieve from https://repository.arizona.edu/handle/10150/604160

Mayoral, P., \& Tello, A (2018). YouTube Based Learning. Retrieve from https://www.researchgate.net/publication/242768696_YouTube_Based_Learning

Mills, G. E. (2007). Action research: A guide for the teacher researcher (3rd ed.). New Jersey, NJ: Pearson.

Palmer, E. (2014). Teaching the core skills of listening \& speaking. Virginia, VA: ASCD.

Park, Y., \& Jung, E. (2016). Exploring the use of video-clips for motivation building in a secondary school EFL setting. English Language Teaching, 9(10), 81-89. https://doi.org/10.5539/elt.v9n10p81

Ramírez Ortiz, S. M., \& Artunduaga Cuéllar, M. T. (2018). Authentic tasks to foster oral production among English as a foreign language learners. HOW, 25(1), 51-68. https://doi.org/10.19183/how.25.1.362

Teaching strategies for using educational movies in the classroom. (2014). In the night owl. Retrieved from https://www.wgu.edu/blogpost/teaching-strategies-using-educational-television-classroom\#

Troute, L. (2016). Oral language and vocabulary development activities for student-student interaction.

Urquijo, J. (2012) Improving oral performance through the use of interactions flashcards. (Undergraduate thesis).

Wang, Z. (2015). An analysis on the use of video materials in college English teaching in China. International Journal of English Language Teaching, 2(1), 23-28.

\section{Copyrights}

Copyright for this article is retained by the author(s), with first publication rights granted to the journal.

This is an open-access article distributed under the terms and conditions of the Creative Commons Attribution license (http://creativecommons.org/licenses/by/4.0/). 